\title{
Controlling Measures for Cost Overrun Causes in Highway Projects of Sindh Province
}

\author{
Samiullah Sohu \\ Department of Civil Engineering, Quaid- \\ e-Awam University of Engineering, \\ Science and Technology, Sindh, Pakistan \\ Engr.samiullah@quest.edu.pk
}

\author{
Abd Halid Abdullah \\ Faculty of Civil and Environmental \\ Engineering, Universiti Tun Hussein Onn \\ Malaysia, Johor, Malaysia \\ abdhalid@uthm.edu.my
}

\author{
Sasitharan Nagapan \\ Faculty of Civil and Environmental \\ Engineering, Universiti Tun Hussein Onn \\ Malaysia, Johor, Malaysia \\ sasitharan@uthm.edu.my
}

\author{
Touqeer Ali Rind \\ Department of Civil Engineering, \\ Mehran University of Engineering and Technology, Shaheed \\ Zulfiqar Ali Bhutto Campus, Khairpur Mirs', Pakistan \\ touqeerali@muetkhp.edu.pk
}

\author{
Ashfaque Ahmed Jhatial \\ Department of Civil Engineering, \\ Mehran University of Engineering and Technology, Shaheed \\ Zulfiqar Ali Bhutto Campus, Khairpur Mirs', Pakistan \\ ashfaqueahmed@muetkhp.edu.pk
}

\begin{abstract}
Cost overrun is a serious issue in the construction industry worldwide, including Pakistan. Cost overrun is a critical and serious issue found in highway projects among all construction projects in Pakistan. Cost overrun occurs when the final cost of the projects exceeds the actual cost of the project. The main objective of this research is to identify the main causes of cost overrun and to determine possible mitigation measures of the identified main causes of cost overrun from contractors of highway/road projects of Pakistan. In this study, a mixed mode (quantitative and qualitative) approach was used. A deep literature review helped to identify the 30 most common causes of cost overrun in the construction industry. In the first stage, a questionnaire was developed, and a survey was carried out among professional and experts who were working with contractors in highway projects. In the second stage, a semistructured questionnaire was developed, and a survey was carried out to determine the possible mitigation measures of the identified main causes of cost overrun. Collected data for the first stage from experts were inserted in SPSS and were analyzed by using the average index method and the data of the second stage were analyzed by content analysis. It is expected that the findings of this research will be useful and helpful for the construction stakeholders to control and mitigate the major causes of cost overrun.
\end{abstract}

Keywords-cost overrun; highway projects; contractors; controlling measures

\section{INTRODUCTION}

The construction industry is known as a major source of economic growth of any country [1]. The construction industry advances the quality standard of living by the construction of infrastructures such as schools, roads, hospitals, etc. [2]. The construction industry is known as a complex in nature and fragmented industry, therefore it is facing critical problems of cost overrun, low quality, time overrun, construction waste, low productivity, etc. Out of these problems, cost overrun is one of the major ones as money is always of high importance $[3,4]$. Cost overrun is a serious issue for developing and developed countries [5]. The basic definition of cost overrun is that the final cost is higher than the one that was budgeted in an earlier stage [6]. In Qatar construction industry more than 50\% of construction projects faced serious issues of cost overrun [7, 8]. As reported in [9], $60 \%$ of construction projects in Singapore were badly affected by cost overrun. According to [10] most construction projects have an experience of an average increase in cost of more than $33 \%$. Cost overrun or budget overrun in the construction projects is known as a universal and regular phenomenon whereas only a few projects are rarely completed within the approved and estimated budget [11]. According to [12], cost overrun is more than $100 \%$ of the total cost of a project in both developed and developing countries.

Pakistan construction industry is also facing this serious issue $[13,14]$, but the issue occurs mostly in highway projects. Construction projects of Pakistan have faced the issue of cost overrun and most projects have crossed $50 \%$ from the actual cost of the project [15]. Although various studies have been conducted on cost overrun in construction projects, only a few have found mitigation measures of the major causes of cost overrun, probable because the causes vary from country to country [16]. Pakistan is a developing country, facing the issue of cost overrun in all types of construction projects especially in highway projects. Therefore, there is a need to explore the major causes of cost overrun in highway projects and determine ways to cope with the problem. Hence, the research objectives of this research are:

- To find the major causes of cost overrun in highways/road projects in Pakistan.

- To determine possible mitigation measures from experienced respondents for the identified causes. 


\section{LITERATURE PEVIEW}

Many researches have studied the causes of cost overrun in different types of construction projects and as a result a number of causes of cost overrun in construction have been found. Authors in [17] identified the most critical causes of cost overrun in construction projects in Afghanistan by conducting a questionnaire survey of 75 respondents from different organizations. The results of the survey concluded that the major causes which affect the total cost of the construction project were delay in process of payments by the client to the contractor, corruption in tendering and billing, financial difficulties, problems faced by the contractor/builder, security issues at the construction site, market inflations, and sudden changes from the client. Authors in [18] carried a quantitative survey which aimed to identify the major causes of cost overrun in Cambodia construction projects. The results of the survey showed that mistakes in the estimation of project cost, lack of communication, and unsuitable construction methods were the main causes of cost overrun. Authors in [19] carried a survey regarding construction projects of India to find the major causes of cost overrun. A questionnaire was distributed among 190 professional experts in the construction industry. The results identified that escalation in raw materials, lack of communication between parties, frequent and sudden design changes, wastage and misuse of materials at the construction site, labor disputes, lack of on-site financial control, owner interference, mistakes during construction, relationship issues, and labor and management issues were the major reasons. A research was conducted in Palestine construction industry by conducting a survey through the distribution of 151 questionnaires to contractors, clients and consultants [20]. Through analysis of the collected data, it was revealed that material, design and documentation, professional management, contractual relationships, external factors, owner's responsibilities, government relations, contractor's responsibilities, consultant's responsibilities, labor and equipment were the major causes of cost overrun. Authors in [21] carried a questionnaire survey and interviewed professionals and experts of the construction industry in South Africa. The outcome of the survey was that incomplete information at the time of tendering, changes in the scope of the project, contractual claims, improper planning for funds, additional works and improper fund monitoring were found as the main causes of cost overrun. Authors in [22] investigated the main causes of cost overrun in Uganda's construction projects by conducting a questionnaire survey. The results of the survey showed that the main causes of cost overrun were high-interest and inflation rates, changes in the scope of the project, poor control and poor monitoring, deficiencies in contract documents, and delay in the process of payments. Authors in [16] recognized the causes of cost overrun by using quantitative method. The main causes were contactor poor site management, additional work, poor supervision, poor project management assistance, rapid design changes, delayed payments of completed works, material cost, unforeseen site conditions, shortages and delay of material arrival at the site, and inaccurate estimates.

Based on [23-36], thirty common causes of cost overrun were identified: inadequate planning, delay in payment process by client, owner interference, poor contract management, delay in decision making, shortage of material, fluctuation in price of materials, financial difficulties by contractor, poor site management, natural disasters, change in material specifications and type, poor financial control at site, mistakes and errors in design, lack of experience of the technical consultant, additional works, mistakes and discrepancies in contract document, accidents, poor design, severe overtime, fraudulent practices and kickboards, the relationship between management and labor, delay in approval, problems with neighbours, complicated design, incompetent subcontractor, inadequate monitoring, inaccurate site investigation, schedule delay, and high labor cost.

Author in [37] conducted research by using the structured questionnaire approach to identify the major factors of cost overrun in transport/highway projects in Canada. Results of the research were that external factors, problems in the estimated cost, changes in design and other conditions were the major factors. Authors in [38] conducted research to find the main causes of cost overrun in highway projects in the UK. The main causes of cost overrun turned out to be changes in design, inflation, changes in the price of materials, complex nature of the project, changes in the scope of the project, contract procedure and inadequate procurement in transport projects of United Kingdom.

\section{RESEARCH METHODOLOGY}

To achieve the objectives of this research, a mixed mode (questionnaire survey and semi-structured questionnaire survey) approach was used. The process of the research method is given below.

An extended literature review was conducted on cost overrun in construction projects, which helped to identify 30 causes of cost overrun in construction projects.

A questionnaire was developed consisting of two parts, namely Part A and Part B. Part A was designed to obtain the personal information of the respondents. Part $\mathrm{B}$ comprised of the common cost overrun causes. A five-point Likert scale was used. Its numeric values ranged from 1 for "extremely significant to 5 for "not significant".

A pilot A study was carried out to check the relevancy of cost overrun causes given in the questionnaire to highway project contractors. The participants were 40 contractors. A total of 39 complete answered questionnaires were received from the respondents and all were valid and considered for further analysis. The response rate for this research was $96 \%$. Mean value (MV) was used to rank the cost overrun causes in highway projects of Pakistan. The cut-off scale was adapted from [39] for the relevancy of cost overrun causes to highway projects, as shown in Table I.

TABLE I. TEST SPECIFICATIONS AND CONDITIONS

\begin{tabular}{|c|c|}
\hline Mean score & Level of relevancy \\
\hline Below 4 & Non-Relevant \\
\hline Above 4 & Relevant \\
\hline
\end{tabular}

Pilot B: A semi-structured questionnaire survey was carried out among 30 professionals and experts working with contractors in handling highway projects, in order to 
determine possible mitigation measures for the major nine cost overrun causes which were identified by an actual questionnaire survey. The collected data were analyzed by content analysis. The educational level and occupation of the respondents are shown in Figures 1 and 2.

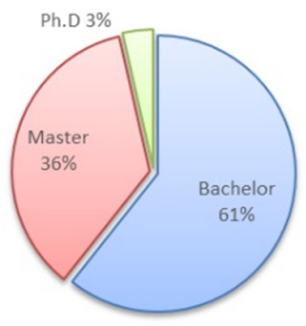

Fig. 1. Academic qualification of respondents

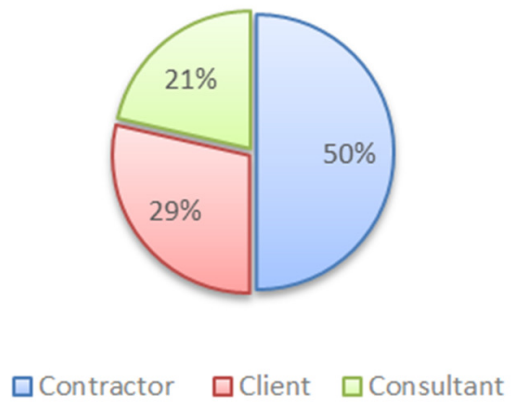

Fig. 2. Occupation of respondents

A quantitative questionnaire was designed and distributed among 100 selected respondents from contractors of highway projects to identify the most significant mitigation measures of major causes of cost overrun. The occupation and the educational level of the selected respondents (contractors) for the actual questionnaire are presented in Figures 3 and 4. The collected data from the actual questionnaire survey were evaluated using SPSS with MV.

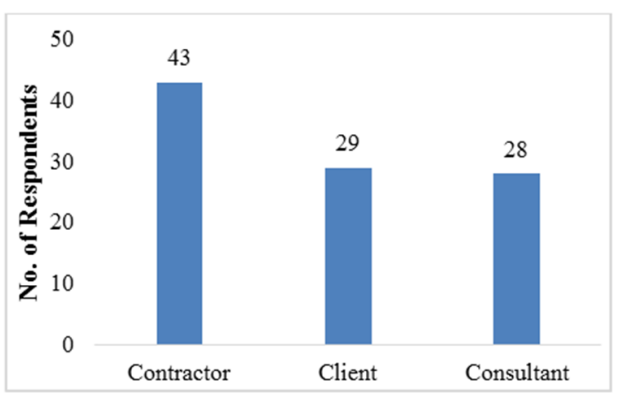

Fig. 3. Occupation of respondents

\section{DATA ANALYSIS, RESULTS AND DISCUSSION}

The Statistical Package for the Social Sciences (SPSS) version 22 was used to check the data off stage one questionnaire. Cronbach's alpha $(\alpha)$ was used to check the reliability of the collected data from the questionnaire survey. The result of the reliability test was 0.894 . According to [40] if the value of Cronbach's alpha is more than 0.7 , then the data are valid and reliable and if the value of Cronbach's alpha is below 0.7 , then the data are not valid and reliable. Thus, since the value of $\alpha$ was above 0.7 , the collected data are valid. Table II shows the major causes of cost overrun which were calculated by using the average index method and having mean value more than 4.0. Table II shows that "Inadequate planning" scored the highest mean value of 4.624 and ranked as the first cause of cost overrun in highway projects. It was followed by "Frequent design changes" and "Financial difficulties faced by the client".

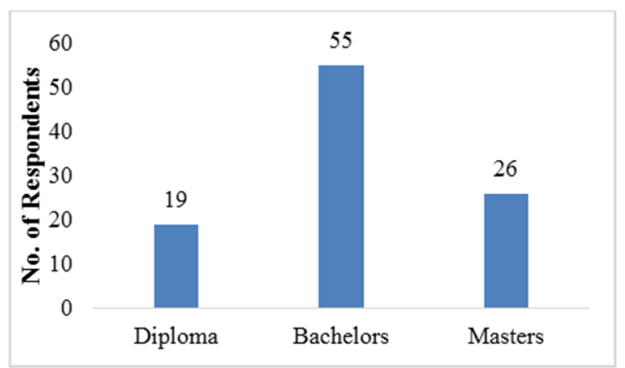

Fig. 4. Academic qualification of respondents

TABLE II. MAJOR CAUSES OF COST OVERRUN

\begin{tabular}{|c|c|c|}
\hline Major Causes & Mean Value & Rank \\
\hline Inadequate planning & 4.624 & $1 \mathrm{st}$ \\
\hline Frequent design changes & 4.468 & $2 \mathrm{nd}$ \\
\hline Financial difficulties faced by the client & 4.468 & $3 \mathrm{rd}$ \\
\hline Owner interference & 4.309 & 4 th \\
\hline Delays in decision making & 4.298 & 5 th \\
\hline Fluctuation of the process in the material & 4.213 & 6 th \\
\hline Poor contract management & 4.188 & 7 th \\
\hline Mistakes in design & 4.115 & 8 th \\
\hline Shortage of labor & 4.027 & 9 th \\
\hline
\end{tabular}

\section{A. Mitigation Measures for the Major Causes of Cost Overrun}

Table III shows the results of the semi-structured questionnaire survey. The possible mitigation measures for major cost overrun causes regarding construction were investigated. These mitigation measures were analyzed by content analysis technique. The results of the semi-structured questionnaire helped get the possible mitigation measures of the 9 main causes of cost overrun. Each cause has a minimum of four possible mitigation measures.

\section{B. Significant Mitigation Measures of Major Causes of Cost Overrun}

Table IV represents the results of the structured questionnaire survey. The most significant mitigation measures for major cost overrun causes were identified by using mean value (MV). The most significant mitigation measures of the major causes of cost overrun had the highest MV. From the at least four possible mitigation measures, the measure having the highest MV was selected as the most significant one. A total of nine significant mitigation measures were identified, one for each of the respective main causes of cost overrun in highway projects. 
TABLE III. SEMI-STRUCTURED QUESTIONNAIRE FOR MITIGATION MEASURES OF MAJOR CAUSES OF COST OVERRUN RESULTS

\begin{tabular}{|c|c|c|}
\hline Causes & Mitigation Measures & Frequency \\
\hline \multirow{4}{*}{$\begin{array}{l}\text { Inadequate } \\
\text { planning }\end{array}$} & $\begin{array}{l}\text { The client should plan each activity before } \\
\text { starting the project }\end{array}$ & 27 \\
\hline & $\begin{array}{l}\text { The planning committee should visit the site } \\
\text { before tendering project }\end{array}$ & 24 \\
\hline & $\begin{array}{c}\text { Competent staff should be appointed in the } \\
\text { planning section }\end{array}$ & 20 \\
\hline & $\begin{array}{l}\text { The project should be planned as per its } \\
\text { scope/need }\end{array}$ & 18 \\
\hline \multirow{4}{*}{$\begin{array}{c}\text { Frequent } \\
\text { design } \\
\text { changes }\end{array}$} & $\begin{array}{l}\text { The complexity of contract/wrong } \\
\text { concept/formulation should be avoided }\end{array}$ & 27 \\
\hline & $\begin{array}{l}\text { Violation of environmental and human safety } \\
\text { should be avoided }\end{array}$ & 24 \\
\hline & $\begin{array}{l}\text { Competent and well-experienced engineers } \\
\text { should be posted/appointed }\end{array}$ & 20 \\
\hline & Details should be provided & 18 \\
\hline \multirow{4}{*}{$\begin{array}{c}\text { Financial } \\
\text { difficulties } \\
\text { faced by the } \\
\text { client }\end{array}$} & $\begin{array}{l}\text { Sufficient funds should be kept for each } \\
\text { project }\end{array}$ & 27 \\
\hline & $\begin{array}{l}\text { Donor/investor should start a project on the } \\
\text { availability of funds }\end{array}$ & 25 \\
\hline & $\begin{array}{l}\text { Funds of the project should not be transferred } \\
\text { to other projects }\end{array}$ & 24 \\
\hline & Government should allocate funds on time & 21 \\
\hline \multirow{4}{*}{$\begin{array}{c}\text { Owner } \\
\text { interference }\end{array}$} & $\begin{array}{c}\text { Appointment of favoured contractors should } \\
\text { be avoided }\end{array}$ & 26 \\
\hline & $\begin{array}{c}\text { Approval and procedural delays should be } \\
\text { avoided }\end{array}$ & 23 \\
\hline & Changes in key posts should be avoided & 20 \\
\hline & Political appointments should be avoided & 17 \\
\hline \multirow{5}{*}{$\begin{array}{l}\text { Delay in } \\
\text { decision } \\
\text { making }\end{array}$} & $\begin{array}{c}\text { Sufficient data \& details should be provided to } \\
\text { take decisions }\end{array}$ & 27 \\
\hline & $\begin{array}{c}\text { A competent and qualified team should be } \\
\text { appointed to take decisions } \\
\end{array}$ & 25 \\
\hline & Favoritism and nepotism should be avoided & 24 \\
\hline & $\begin{array}{l}\text { Communication between parties should be } \\
\text { adopted to expedite activities at project }\end{array}$ & 22 \\
\hline & $\begin{array}{l}\text { The client should arrange frequent meetings } \\
\text { with all involved engineers }\end{array}$ & 19 \\
\hline \multirow{4}{*}{$\begin{array}{c}\text { Fluctuation of } \\
\text { material } \\
\text { prices }\end{array}$} & $\begin{array}{l}\text { Proper planning and scheduling should be } \\
\text { adopted }\end{array}$ & 28 \\
\hline & $\begin{array}{l}\text { Proper policies should be adopted by the } \\
\text { Government }\end{array}$ & 26 \\
\hline & Sufficient material should be stored & 25 \\
\hline & $\begin{array}{l}\text { Inordinate delay in project implementation } \\
\text { should be avoided }\end{array}$ & 23 \\
\hline \multirow{4}{*}{$\begin{array}{c}\text { Poor contract } \\
\text { management }\end{array}$} & $\begin{array}{l}\text { A qualified team should be appointed until the } \\
\text { completion of the project }\end{array}$ & 26 \\
\hline & $\begin{array}{l}\text { Planning and scheduling should be done for } \\
\text { every activity }\end{array}$ & 23 \\
\hline & $\begin{array}{c}\text { Coordination between parties should be } \\
\text { adopted }\end{array}$ & 22 \\
\hline & $\begin{array}{l}\text { Daily routine matters should be recorded at } \\
\text { the site }\end{array}$ & 20 \\
\hline \multirow{4}{*}{$\begin{array}{l}\text { Mistakes in } \\
\text { design }\end{array}$} & Favoritism should be avoided & 29 \\
\hline & $\begin{array}{l}\text { Experienced consultant in highway } \\
\text { construction should be appointed }\end{array}$ & 27 \\
\hline & $\begin{array}{l}\text { Experienced staff under consultant should be } \\
\text { appointed }\end{array}$ & 25 \\
\hline & $\begin{array}{c}\text { Consultants profile should be evaluated before } \\
\text { awarding of the project }\end{array}$ & 23 \\
\hline \multirow{4}{*}{$\begin{array}{l}\text { Shortage of } \\
\text { labor }\end{array}$} & $\begin{array}{l}\text { Sufficient facilities should be given to skilled } \\
\text { labor }\end{array}$ & 28 \\
\hline & High wages should be paid to skilled labor & 26 \\
\hline & Training should be given to unskilled labor & 25 \\
\hline & $\begin{array}{l}\text { Government should adopt policies so that } \\
\text { maximize skilled labor }\end{array}$ & 22 \\
\hline
\end{tabular}

TABLE IV. MAJOR CAUSES AND MITIGATION MEASURES

\begin{tabular}{|c|c|c|}
\hline Major causes & Mitigation measures & MV \\
\hline planning & $\begin{array}{c}\text { The client should plan each activity before } \\
\text { starting the project }\end{array}$ & 4.592 \\
\hline $\begin{array}{c}\text { Frequent design } \\
\text { changes }\end{array}$ & Details should be provided & 4.297 \\
\hline $\begin{array}{c}\text { Financial } \\
\text { difficulties faced by } \\
\text { the client }\end{array}$ & $\begin{array}{c}\text { Donor/investor should start a project on the } \\
\text { availability of funds }\end{array}$ & 4.319 \\
\hline Owner interference & $\begin{array}{c}\text { Approval and procedural delays should be } \\
\text { avoided }\end{array}$ & 4.571 \\
\hline $\begin{array}{c}\text { Delay in decision } \\
\text { making }\end{array}$ & $\begin{array}{c}\text { A competent and qualified team should be } \\
\text { appointed to take decisions }\end{array}$ & 4.329 \\
\hline $\begin{array}{c}\text { Fluctuation of } \\
\text { material prices }\end{array}$ & $\begin{array}{c}\text { Proper policies should be adopted by the } \\
\text { Government }\end{array}$ & 4.571 \\
\hline $\begin{array}{c}\text { Poor contract } \\
\text { management }\end{array}$ & $\begin{array}{c}\text { A qualified team should be appointed until } \\
\text { the completion of the project }\end{array}$ & 4.331 \\
\hline Mistakes in design & $\begin{array}{c}\text { Experienced consultant in highway } \\
\text { construction should be appointed }\end{array}$ & 4.297 \\
\hline Shortage of labor & $\begin{array}{c}\text { Sufficient facilities should be given to } \\
\text { skilled labor }\end{array}$ & 4.235 \\
\hline
\end{tabular}

\section{CONCLUSION}

Cost overrun is one of the major and serious issues the construction industry is facing, especially in highway projects. A thorough literature review was conducted, and a questionnaire was designed consisting of 30 main causes identified from previous studies. Out of these 30 causes, 9 major causes of cost overrun were identified from professionals working with contractors in highway projects of Pakistan. A semi-structured questionnaire survey offered a source of information based on the participants' experience in relation to controlling major causes of cost overrun. A structured questionnaire was designed on the findings of the semistructured questionnaire and was distributed among 100 randomly selected respondents working with contractors, which helped to identify the most significant controlling measures for the major causes of cost overrun in highway/road projects. The findings of this research are going to be useful to the stakeholders of the construction of highway projects.

\section{REFERENCES}

[1] A. A. Jhatial, S. Sohu, N. K. Bhatti, M. T. Lakhiar, R. Oad, "Effect of steel fibres on the compressive and flexural strength of concrete", International Journal of Advanced and Applied Sciences, Vol. 5, No. 10, pp. 16-21, 2018

[2] Y. Al-Emad, N. Hamid, Structural Relationships Model of Delay Factors in Makkah Construction Industry, Universiti Tun Hussein Onn Malaysia, 2016

[3] I. Mahamid, N. Dmaidi, "Risks leading to cost overrun in building construction from consultants' perspective", Organization, Technology and Management in Construction: An International Journal, Vol. 5, No. 2, pp. 860-873, 2013

[4] D. M. Matin, "Identifying the effective factors for cost overrun and time delay in water construction projects", Engineering, Technology \& Applied Science Research, Vol. 6, No. 4, pp. 1062-1066, 2016

[5] S. Sohu, A. H. Abdullah, S. Nagapan, A. A. Jhatial, K. Ullah, I. A. Bhatti, "Significant mitigation measures for critical factors of cost overrun in highway projects of Pakistan", Engineering, Technology \& Applied Science Research, Vol. 8, No. 2, pp. 2270-2274, 2018

[6] M. Siemiatycki, Cost Overruns on Infrastructure Projects: Patterns, Causes, and Cures, Institute on Municipal Finance and Governance, 2015 
[7] A. Senouci, A. Ismail, N. Eldin, "Time delay and cost overrun in Qatari public construction projects”, Procedia Engineering, Vol. 164, pp. 368375,2016

[8] M. A. Akhund, H. U. Imad, N. A. Memon, F. Siddiqui, A. R. Khoso, A. A. Panhwar, "Contributing factors of time overrun in public sector construction projects", Engineering, Technology \& Applied Science Research, Vol. 8, No. 5, pp. 3369-3372, 2018

[9] K. Yongjian, F. Y. Y. Ling, Y. Ning, "Public construction project delivery process in Singapore, Beijing, Hong Kong and Sydney", Journal of Financial Management of Property and Construction, Vol. 18, No. 1, pp. 6-25, 2013

[10] J. R. Hartley, Concurrent Engineering: Shortening Lead Times, Raising Quality, and Lowering Costs, Routledge, 2017

[11] A. Aljohani, D. Ahiaga-Dagbui, D. Moore, "Construction projects cost overrun: What does the literature tell us?", International Journal of Innovation, Management and Technology, Vol. 8, No. 2, pp. 137-143, 2017

[12] U. S. Vaardini, S. Karthiyayini, P. Ezhilmathi, "Study no cost overruns in construction projects-a review", International Journal of Applied Engineering Research, Vol. 11, No. 3, pp. 356-363, 2016

[13] S. Sohu, A. H. Abdullah, S. Nagapan, A. Fattah, K. Ullah, K. Kumar, "Contractor's perspective for critical factors of cost overrun in highway projects of Sindh, Pakistan", in: Proceedings of the International Conference of Global Network for Innovative Technology and AWAM International Conference in Civil Engineering (IGNITE-AICCE'17), pp. 080002-1-080002-6, AIP Publishing, 2017

[14] M. Ali, S. A. Mangi, S. Sohu, Q. B. Jamali, K. Ullah, "Major factors of budget overrun in construction of road projects of Sindh,Pakistan", Engineering Science and Technology International Research Journal, Vol. 1, No. 2, pp. 28-32, 2017

[15] S. Sohu, A. H. Abdullah, S. Nagapan, N. A. Memon, R. Yunus, M. F. Hasmori, "Causative factors of cost overrun in building projects of Pakistan”, International Journal of Integrated Engineering, Vol. 10, No. 9, pp. 122-126, 2018

[16] S. Kim, K. N. Tuan, V. T. Luu, "Delay factor analysis for hospital projects in Vietnam", KSCE Journal of Civil Engineering, Vol. 20, No. 2, pp. 519-529, 2015

[17] G. A. Niazi, N. Painting, "Significant factors causing cost overruns in the construction industry in Afghanistan", Procedia Engineering, Vol. 182 , pp. $510-517,2017$

[18] S. Durdyev, M. Omarov, S. Ismail, M. Lim, "Significant contributors to cost overrun in construction projects of Cambodia", Cogent Engineering, Vol. 4, No. 1, pp. 1-10, 2017

[19] S. P. Wanjari, G. Dobariya, "Identifying factors causing cost overrun of the construction projects in India", Sadhana, Vol. 41, No. 6, pp. 679693, 2016

[20] A. Enshassi, J. Al-Najjar, M. Kumaraswamy, "Delays and cost overruns in the construction projects in the Gaza Strip", Journal of Financial Management of Property and Construction, Vol. 14, No. 2, pp. 126-151, 2009

[21] M. S. Ramabodu, J. J. P. Verster, "Factors Contributing to Cost Overruns of Construction Projects", 5th Built Environment Conference Factors Contributing to Cost Overruns of Construction Projects, Durban, South Africa, July 18-20, 2010

[22] H. Alinaitwe, R. Apolot, D. Tindiwensi, "Investigation into the causes of delays and cost overruns in Uganda's public sector construction projects", Journal of Construction in Developing Countries, Vol. 18, No. 2, pp. 33-47, 2013

[23] P. T. Gbahabo, O. S. Ajuwon, "Effects of project cost overruns and schedule delays in Sub-Saharan Africa", European Journal of Interdisciplinary Studies, Vol. 3, No. 2, pp. 46-59, 2017

[24] M. A. Akhund, A. R. Khoso, U. Memon, S. H. Khahro, "Time overrun in construction projects of developing countries", Imperial Journal of Interdisciplinary Research, Vol. 3, No. 5, pp. 124-129, 2017

[25] A. H. Memon, I. A. Rahman, M. R. Abdullah, A. A. A. Azis, "Factors affecting construction cost performance in project management projects: Case of MARA large projects", International Journal of Civil Engineering and Built Environment, Vol. 1, No. 1, pp. 30-35, 2014
[26] Z. Shehu, I. R. Endut, A. Akintoye, "Factors contributing to project time and hence cost overrun in the Malaysian construction industry", Journal of Financial Management of Property and Construction, Vol. 19, No. 1, pp. 55-75, 2014

[27] S. Z. H. S. Jamaludin, M. F. Mohammad, K. Ahmad, "Enhancing the quality of construction environment by minimizing the cost variance", Procedia-Social and Behavioral Sciences, Vol. 153, pp. 70-78, 2014

[28] N. Roslan, N. Y. Zainun, A. H. Memon, "Measures for controlling time and cost overrun factors during execution stage", International Journal of Construction Technology and Management, Vol. 1, No. 1, pp. 8-11, 2014

[29] A. S. Ali, S. N. Kamaruzzaman, "Cost performance for building construction projects in Klang Valley", Journal of Building Performance, Vol. 1, No. 1, pp. 110-114, 2010

[30] N. Azhar, R. U. Farooqui, S. M. Ahmed, "Cost Overrun Factors In Construction Industry of Pakistan", First International Conference on Construction in Developoing Countries, Karachi, Pakistan, August 4-5, 2008

[31] M. Sambasivan, Y. W. Soon, "Causes and effects of delays in Malaysian construction industry", International Journal of Project Management, Vol. 25, No. 5, pp. 517-526, 2007

[32] D. S. Tejale, S. D. Khandekar, J. R. Patil, "Analysis of construction project cost overrun by statistical method", International Journal of Advance Research in Computer Science and Management Studies, Vol. 3, No. 5, pp. 349-355, 2015

[33] H. Samarghandi, S. M. M. Tabatabaei, P. Taabayan, A. M. Hashemi, K. Willoughby, "Studying the reasons for delay and cost overrun in construction projects: The case of Iran", Journal of Construction in Developing Countries, Vol. 21, No. 1, pp. 51-84, 2016

[34] M. Baek, K. Mostaan, B. Ashuri, "Recommended Practices for the Cost Control of Highway Project Development”, Construction Research Congress, Puerto Rico, 2016

[35] Z. T. Zewdu, G. T. Aregaw, "Causes of contractor cost overrun in construction projects: The case of Ethiopian construction sector", International Journal of Business and Economics Research, Vol. 4, No. 4, pp. 180-191, 2015

[36] G. B. E. Elanga, P. Louzolo-Kimbembe, C. Pettang, "Evaluation of cost overrun factors in the construction projects in developing countries: Cameroon as case study", International Journal of Emerging Technology and Advanced Engineering, Vol. 4, No. 10, pp. 533-538, 2014

[37] S. M. Vidalis, F. T. Najafi, "Cost and Time Overruns in Highway Construction", Canadian Society for Civil Engineering-30th Annual Conference: 2002 Challenges Ahead, Montreal, Canada, June 5-8, 2002

[38] W. J. Hamid, A. Waterman, "Analysis of the main causes of cost overruns in construction industry in developing countries and the UK", International Review of Civil Engineering, Vol. 9, No. 3, pp. 105-113, 2018

[39] L. Muhwezi, L. M. Chamuriho, N. M. Lema, "An investigation into materials wastes on building construction projects in Kampala-Uganda", Scholarly Journal of Engineering Research, Vol. 1, No. 1, pp. 11-18, 2012

[40] L. Xin, W. Rong, "Survey Research on Relationship Among Service Failures, Service Recovery and Customer Satisfaction", International Conference on Management Science and Engineering, Harbin, China, August 20-22, 2007 